\title{
Invasive Fungal Infections in Children with Leukemia: Clinical Features and Prognosis
}

\author{
Lösemili Çocuklarda Invazif Mantar Enfeksiyonlarr: Klinik Özellikler ve Prognoz
}

\author{
(D) Melike Sezgin Evim¹, (D) Özlem Tüfekçi², (D) Birol Baytan¹, (D) Hale Ören², (D) Solmaz Çelebi³, (D) Beyza Ener4, (D) Kevser Üstün Elmas5, \\ (D) Şebnem Yılmaz², (D) Melek Erdem², (D) Mustafa Kemal Hacımustafaoğlu³, (D) Adalet Meral Güneş1
}

1 Uludağ University Faculty of Medicine, Department of Pediatric Hematology, Bursa, Turkey

2Dokuz Eylül University Faculty of Medicine, Department of Pediatric Hematology, Izmir, Turkey

3Uludağ University Faculty of Medicine, Department of Pediatric Infection Disease, Bursa, Turkey

4 Uludağ University Faculty of Medicine, Department of Medical Microbiology, Bursa, Turkey

5 Uludağ University Faculty of Medicine, Department of Pediatrics, Bursa, Turkey

\section{Abstract}

Objective: The incidence of invasive fungal infections (IFIs) has increased due to intensive chemotherapy in childhood leukemia. The aim of this study was to evaluate the incidence, risk factors, causative pathogens, and impact on survival of IFls among pediatric leukemia patients.

Materials and Methods: The hospital records of 307 children with acute lymphoblastic leukemia $(A L L, n=238)$, acute myeloid leukemia (AML, $n=51)$, and relapsed leukemia $(n=18)$ between January 2010 and December 2015 were retrospectively evaluated.

Results: A total of 1213 febrile neutropenia episodes were recorded and $127(10.4 \%)$ of them were related to an IFI. Of 307 children, 121 (39.4\%) developed IFls. The mean age was significantly older in the IFI group compared to children without IFIs $(p<0.001)$. IFIs were defined as possible, probable, and proven in $73.2 \%, 11.9 \%$, and $14.9 \%$ of the attacks, respectively. Invasive aspergillosis (81.9\%) was the most frequent infection, followed by invasive candidiasis (13.4\%) and rare fungal diseases (4.8\%). The majority of IFI attacks in both ALL and AML occurred during the induction phase. In total, the death rate was $24 \%$ and the IFI-related mortality rate was $18 \%$. The mortality rate among children with IFIs was found to be significantly higher than that of children without IFIs ( $p<0.001)$. Overall and event-free survival rates at 5 years were also found to be significantly lower in the IFI group ( $p<0.001)$. Relapse (odds ratio: 8.49 ) was the most effective risk factor for mortality, followed by developing an IFI episode (odds ratio: 3.2) and AML (odds ratio: 2.33) according to multivariate regression analysis.

Conclusion: Our data showed that IFls were more common in older children. Although proven and probable IFI episodes were more frequently diagnosed in cases of relapse and $A M L$, children with $A L L$ and $A M L$ had similar frequencies of experiencing at least one episode

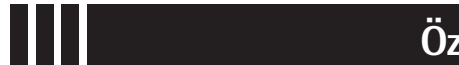

Amaç: Çocukluk çağı lösemisinde yoğun kemoterapi nedeniyle invaziv mantar enfeksiyonlarının (IFI) insidansı artmıştır. Bu çalışmanın amacı, pediatrik lösemi hastalarında IFI'nın insidansını, risk faktörlerini, nedensel patojenleri ve sağkalım üzerindeki etkisini değerlendirmektir.

Gereç ve Yöntemler: Ocak 2010 ile Aralık 2015 tarihleri arasında akut lenfoblastik lösemili ( $A L L, n=238)$, akut myeloid lösemili $(A M L, n=51)$ ve relaps lösemili $(n=18) 307$ çocukların hastane kayıtları geriye dönük olarak değerlendirildi.

Bulgular: Toplam 1213 febril nötropeni atağı kaydedildi ve bunların 127 'si $(\% 10,4)$ IFI ile ilgiliydi. Bu 307 çocuğun 121'i $(\% 39,4)$ IFI geliştirdi. Ortalama yaş, IFI grubunda IFI olmayan çocuklara kıyasla anlamlı olarak daha büyük bulundu $(p<0,001)$. IFI, atakları sırasıyla; $\% 73,2, \% 11,9$ ve \%14,9'unda olası, yüksek olası ve kanıtlanmış olarak tanımlandı. İnvazif aspergilloz $(\% 81,9)$ en sık görülen enfeksiyondu, bunu invaziv kandidiyazis $(\% 13,4)$ ve nadir mantar hastalıkları $(\% 4,8)$ izledi. Hem ALL hem de AML'deki IFI ataklarının çoğu indüksiyon aşamasında görüldü. Toplamda ölüm oranı \%24 ve IFI bağlantılı ölüm oranı \%18 olarak bulundu. IFI'lı çocuklarda ölüm oranı, IFI olmayan çocuklarda anlamlı olarak daha yüksek bulundu $(p<0,001)$. Beş yılda genel ve olaysız sağkalım, IFI grubunda önemli ölçüde daha düşük bulundu ( $p<0,001)$. Relaps (odds oranı, 8,49), mortalite üzerinde en etkili risk faktörü oldu ve bunu, çok değişkenli regresyon analizi ile bir IFI epizodu geçirmek (odds oranı, 3,2) ve AML olmak (odds oranı, 2,33) izledi.

Sonuç: Çalışmamız, IFI'nın büyük yaştaki çocuklarda daha yaygın olduğunu gösterdi. Kanıtlanmış ve olası IFI epizodlarının nüks ve AML'de daha sık saptanmasına karşın, ALL ve AML'li çocukların da benzer sıklıkta en az bir IFI atağı geçirdiği görüldü. Nadir mantar

๑Copyright 2022 by Turkish Society of Hematology

Turkish Journal of Hematology, Published by Galenos Publishing House

口]. Address for Correspondence/Yazışma Adresi: Melike Sezgin Evim, M.D., Uludağ University Faculty of Medicine, Department of Pediatric Hematology, Bursa, Turkey

E-mail : melikevim@yahoo.com ORCID: orcid.org/0000-0002-4792-269X

Received/Geliş tarihi: March 25, 2021 Accepted/Kabul tarihi: November 17, 2021 


\section{Abstract}

of IFI. Rare fungal diseases were also identified as a major problem. Despite success in treatment, IFls increased the rate of mortality in children with acute leukemia.

Keywords: Fungal infections, Pediatric leukemia, Acute lymphoblastic leukemia, Acute myeloid leukemia, Febrile neutropenia

\section{$\ddot{\mathrm{O} z}$}

hastalıkları önemli bir sorun olarak tanımlandı. Tedavideki başarıya rağmen, IFI'nın akut Iösemili çocuklarda ölüm oranını artırdığı saptandı.

Anahtar Sözcükler: Mantar enfeksiyonları, Pediatrik lösemi, Akut lenfoblastik lösemi, Akut myeloid lösemi, Febril nötropeni

\section{Introduction}

The overall survival (OS) rate of pediatric acute leukemia has improved over the years, reaching 90\% for acute lymphoblastic leukemia (ALL) and 70\% for acute myeloid leukemia (AML) $[1,2]$. However, invasive fungal infections (IFIs) are still a significant cause of mortality and morbidity in children with hematologic malignancies [3]. It is hard to estimate the true incidence of IFls, but it has been increasing in recent years due to advances in diagnostic methods, the use of intensive chemotherapy, prolonged neutropenia, and the increased use of central catheters $[3,4]$. Although new antifungals are available, IFIrelated mortality still remains high, reported to be between $20 \%$ and $70 \%$ in various studies $[4,5,6,7,8]$.

The aim of this study was to evaluate the incidence, risk factors, causative pathogens, and impact of IFls on survival among pediatric acute leukemia patients treated with Berlin-FrankfurtMunich (BFM) protocols in two major pediatric hematology centers of Turkey.

\section{Materials and Methods}

The medical records of acute leukemia patients diagnosed between 2010 and 2015 in the pediatric hematology departments of Uludağ and Dokuz Eylül University Hospitals were retrospectively evaluated. The study included only children with ALL and AML, excluding hematopoietic stem cell recipients. De nova ALL and AML patients were treated with BFM-based protocols (ALL IC-BFM 2009 and AML-BFM 2004 and 2012). ALL-REZ BFM 2002 was used for relapsed ALL and cases of relapsed AML were treated according to AML-REZ BFM 2001/01. A total of 307 patients' data were eligible for evaluation. Febrile neutropenia attacks were analyzed for defining and classifying IFls according to the European Organization for the Research and Treatment of Cancer/Mycoses Study Group (EORTC/MSG) classification system [9]. Based on this classification, probable IFI requires the presence of a host factor, a clinical criterion, and a mycological criterion. Cases that meet the criteria for a host factor and the clinical criterion without a mycological criterion are considered as possible IFI. Proven IFI is defined as fungus detected by either histological analysis or culturing of a specimen of tissue taken from a site of disease.
The patients were hospitalized in single rooms without highefficiency particulate air filtered systems. Data including age, gender, leukemia type, risk groups, treatment phase, duration of neutropenia, and steroid use prior to the diagnosis of IFI were collected from patients' files. Neutropenia was defined as an absolute neutrophil count (ANC) below $500 / \mathrm{mm}^{3}$ and severe neutropenia was defined as an ANC below $100 / \mathrm{mm}^{3}$. Bacterial and fungal surveillances were performed for peripheral blood, central venous catheters, throat, urine, and stool. Tissue biopsy from the affected site for mycological examination was evaluated when available. Chest high-resolution computed tomography (HRCT) and abdominal ultrasound were performed within the first week of persistent fever in spite of proper antimicrobial treatment. In the presence of a localized finding or persistent, prolonged fever, sinonasal and cranial imaging (magnetic resonance imaging or computed tomography scan) were also performed. Serum galactomannan (GM) levels were measured twice weekly during febrile episodes using the Platelia Aspergillus Enzyme Immunoassay Test (Bio-Rad). Samples with an index greater than 0.5 in two consecutive measurements were considered positive. The use of antifungal drugs for either prophylaxis or treatment was recorded. The survival rates and the risk factors affecting mortality in children with IFls and without IFls were compared. The study was approved by the relevant ethics committee on October 4, 2016 (decision number: 2016-17/12).

\section{Statistical Analysis}

All statistical analyses were carried out using IBM SPSS Statistics 23.0 (IBM Corp.). Descriptive data were presented as median and minimum-maximum. Variables with non-normal distribution were analyzed using the Mann-Whitney $\mathrm{U}$ and chi-square tests. Risk factors for mortality were assessed using univariate and multivariate logistic regression analysis. Values of $p<0.05$ were considered statistically significant. Analyses for event-free survival (EFS) and OS rates were performed according to the Kaplan-Meier method, and survival curves were compared with the log-rank test.

\section{Results}

The data of a total of 307 pediatric patients with acute leukemia were retrospectively screened. Of these, 289 cases were de novo 
acute leukemia $(A L L=238, A M L=51)$ and the rest $(n=18)$ were relapsed cases. In total, 1213 febrile neutropenia episodes were recorded and 127 (10.4\%) of them were related to IFIs according to the EORTC/MSG criteria. IFI developed in 121 children (39.4\%). The median age of the whole cohort was 78 (1.7-215.7) months and it was found to be significantly higher in the IFI group $(n=121)$ compared to the children without IFIs $(n=186)$ (96 months vs. 58 months; $p<0.001$ ). The male-to-female ratio was $1.47(n=183 / 124)$. No significant difference was determined in terms of gender ( $p>0.05)$.

\section{Classification of IFIs}

The distributions of patients and episodes of IFI are shown in Table 1. According to the EORTC/MSG criteria, the episodes were classified as proven (14.9\%; $n=19 / 127)$, probable $(11.9 \%$; $n=15 / 127)$, or possible $(73.2 \% ; n=93 / 127)$. In total, $35.2 \%$ $(n=84 / 238)$ of $A L L, 39 \%(n=20 / 51)$ of $A M L$, and $94.4 \%(n=17 / 18)$ of relapsed patients experienced at least one episode of IFI. The incidences of proven and probable IFI episodes were evaluated together and found to be significantly higher in the relapsed leukemia group compared to the de novo ALL and AML patients $(p<0.001)$.

Neutropenia was present in $82 \%(n=104 / 127)$ and severe neutropenia was demonstrated in $73 \%(n=76 / 104)$ of all IFI episodes. The median duration of neutropenia was 20 (1-78) days. The group with proven or probable IFI together had a significantly longer median duration of neutropenia than the possible IFI cases (30 days vs. 16 days; $p=0.002$ ). The frequency of IFI attacks in the ALL group was higher during induction therapy $(n=55 / 87)$, followed by high-risk blocks $(n=18 / 87)$ and the consolidation phase $(n=14 / 87)$. In AML cases, IFIs usually occurred during induction (72.7\%, $n=16 / 22)$.

Mycologic agents isolated during the episodes are given in
Table 2. The majority of IFI episodes were related to invasive aspergillosis (IA) (81.9\%), followed by invasive candidiasis (IC) $(13.4 \%)$ and rare fungal infections (4.8\%). The features of rare fungal infections are given in Table 3.

Generally, children with ALL in the high-risk group received fluconazole prophylaxis while AML and relapse patients had posaconazole or itraconazole. Access to posaconazole is restricted over 13 years of age in Turkey. For younger children, it could only be administered with the special approval of the Turkish Ministry of Health. In the IFI group, 40\% of the episodes occurred under antifungal prophylaxis; the rates of IFI attacks in $A L L, A M L$, and relapsed leukemia cases were $30 \%(n=26 / 87)$, $50 \%(n=11 / 22)$, and $77 \%(n=14 / 18)$, respectively. Children with proven or probable episodes were under antifungal prophylaxis at the time of $21 \%(n=4 / 19)$ and $80 \%(n=12 / 15)$ of the episodes, respectively. The most commonly used antifungal agents for prophylaxis were fluconazole (42.9\%), itraconazole suspension $(33.3 \%)$, and posaconazole $(17.2 \%)$. Secondary antifungal prophylaxis was administered for $63 \%(n=80 / 127)$ of the IFI episodes and the major preferred agent was voriconazole (46\%).

For the treatment of IFI episodes, voriconazole (38\%, $n=49 / 127)$, caspofungin (22.8\%, $n=29 / 127)$, or liposomal amphotericin B $(11 \%, n=14 / 127)$ was given as a single agent. Combination therapy was administered in $27 \%(n=35 / 127)$ of the attacks when the disease was not taken under control by a single agent. Caspofungin and voriconazole $(n=13 / 35)$ were the most commonly preferred combination therapy.

\section{Outcome}

In the whole cohort, the 5-year OS and EFS rates were found to be $83.6 \%$ and $79 \%$ for $A L L, 68.7 \%$ and $60.8 \%$ for $A M L$, and $22 \%$ and $17.6 \%$ for relapsed leukemia cases. In total, the mortality rate was $24 \%(n=72 / 307)$. It was found to be significantly

Table 1. Distribution of patients and episodes of invasive fungal infections according to diagnosis.

\begin{tabular}{|l|l|l|l|l|}
\hline & Total, $\mathbf{n}$ & ALL, \% (n) & AML, \% (n) & $\begin{array}{l}\text { Relapsed } \\
\text { leukemia, \% (n) }\end{array}$ \\
\hline Total patients & 307 & $77.6 \%(238 / 307)$ & $16.6 \%(51 / 307)$ & $5.8 \%(18 / 307)$ \\
\hline Patients without IFI & $60.6 \%(186 / 307)$ & $82.7 \%(154 / 186)$ & $16.6 \%(31 / 186)$ & $0.7 \%(1 / 186)$ \\
\hline Patients with IFI & $39.4 \%(121 / 307)$ & $69.4 \%(84 / 121)$ & $16.5 \%(20 / 121)$ & $14.1 \%(17 / 121)$ \\
\hline Total IFI episodes & 127 & $68.5 \%(87 / 127)$ & $17.3 \%(22 / 127)$ & $14.2 \%(18 / 127)$ \\
\hline Possible & $73.2 \%(93 / 127)$ & $80.5 \%(70 / 87)$ & $68.2 \%(15 / 22)$ & $44.5 \%(8 / 18)$ \\
\hline Probable & $11.9 \%(15 / 127)$ & $8 \%(7 / 87)$ & $9.1 \%(2 / 22)$ & $33.3 \%(6 / 18)$ \\
\hline Proven & $14.9 \%(19 / 127)$ & $11.5 \%(10 / 87)$ & $22.7 \%(5 / 22)$ & $22.2 \%(4 / 18)$ \\
\hline Proven + probable & $28.8 \%(34 / 127)$ & $19.5 \%(17 / 87)$ & $31.8 \%(7 / 22)$ & $55.5 \%(10 / 18)^{*}$ \\
\hline ALL: Acute lymphoblastic leukemia, AML: acute myeloid leukemia, IFl: invasive fungal infection, ${ }^{*}: p<0.001$. & & \\
\hline
\end{tabular}


higher in the IFI group $(34 \%, n=41 / 121)$ compared to the nonIFI group $(16.6 \%, n=31 / 186)(p<0.001)$. IFI-related mortality was observed in $18 \%(n=22 / 121)$ of cases (Figure 1$)$. The mortality rate in children with IFls increased to $52.9 \%(n=18 / 34)$ when possible IFI attacks were excluded. Five-year EFS and OS rates were found to be significantly lower in the IFI group than in cases without IFIs (EFS: $79.6 \%$ vs. $62.7 \%$, OS: $83.9 \%$ vs. $67.5 \%$ ) $(p<0.001)$ (Figure 2). Both EFS and OFS at 5 years in the IFI group were found to be even lower when possible IFI attacks were removed from the analysis (47.1\%).

\begin{tabular}{|c|c|c|c|c|}
\hline Diagnosis of IFI & $\begin{array}{l}\text { Episodes of IFI } \\
(n=127)\end{array}$ & $\begin{array}{l}\text { Proven IFI, } \\
14.9 \%(n=19)\end{array}$ & $\begin{array}{l}\text { Probable IFI, } \\
11.9 \%(n=15)\end{array}$ & $\begin{array}{l}\text { Possible IFI, } \\
73.2 \%(n=93)\end{array}$ \\
\hline Invasive aspergillosis & $81.9 \%(n=104)$ & 3 & 15 & 86 \\
\hline IPA & $76.3 \%(n=97)$ & - & 15 & 82 \\
\hline SNIA & $4.8 \%(n=6)$ & $3^{*}$ & - & 3 \\
\hline CNSIA & $0.8 \%(n=1)$ & - & - & 1 \\
\hline Invasive candidiasis & $13.4 \%(n=17)$ & $10^{* *}$ & - & 7 \\
\hline $\mathrm{HSC}$ & $7.8 \%(n=10)$ & 3 & - & 7 \\
\hline Candidemia & $6.3 \%(n=7)$ & 7 & - & - \\
\hline Rare fungal inf. & $4.8 \%(n=6)^{* * *}$ & 6 & - & - \\
\hline Mucorales & $(n=3)$ & 3 & - & - \\
\hline Fusarium & $(n=1)$ & 1 & - & - \\
\hline Dematiaceous & $(n=1)$ & 1 & - & - \\
\hline Alternaria & $(n=1)$ & 1 & - & - \\
\hline
\end{tabular}

\begin{tabular}{|c|c|c|c|c|c|c|}
\hline $\begin{array}{l}\text { Rare fungal } \\
\text { infection }\end{array}$ & Diagnosis & $\begin{array}{l}\text { Age, } \\
\text { months }\end{array}$ & $\begin{array}{l}\text { Primary } \\
\text { prophylaxis }\end{array}$ & Biopsy region & Treatment & Status \\
\hline Mucorales & Relapsed AML & 40 & Posaconazole & Left maxillectomy & $\begin{array}{l}\text { Liposomal } \\
\text { amphotericin B }\end{array}$ & $\begin{array}{l}\text { Death due to } \\
\text { resistant disease }\end{array}$ \\
\hline Mucorales & ALL-HRG & 204 & No & Sinonasal cavity & $\begin{array}{l}\text { Liposomal } \\
\text { amphotericin B }\end{array}$ & Death due to IFI \\
\hline Mucorales & ALL-HRG & 40 & No & Sinonasal cavity & $\begin{array}{l}\text { Liposomal } \\
\text { amphotericin B }\end{array}$ & Death due to IFI \\
\hline Fusarium & Relapsed ALL & 196 & Posaconazole & Sinonasal cavity & $\begin{array}{l}\text { Liposomal } \\
\text { amphotericin B }\end{array}$ & Death due to IFI \\
\hline Dematiaceous & AML & 52 & No & Sinonasal cavity & Caspofungin & Alive \\
\hline Alternaria & ALL & 182 & No & Sinonasal cavity & $\begin{array}{l}\text { Liposomal } \\
\text { amphotericin B }\end{array}$ & Alive \\
\hline
\end{tabular}




\section{Factors Affecting Mortality}

For 307 children, the risk factors affecting mortality were evaluated by univariate regression analysis. This revealed that high-risk ALL $(n=30)$ and AML $(n=51)$, relapse $(n=18)$, neutropenia longer than 10 days $(n=67)$, development of an IFI episode, and presence of proven or probable IFI significantly increased the rate of mortality $(p<0.001)$. Gender and age at diagnosis did not have any effect $(p>0.05)$.
Independent risk factors for mortality were determined by multivariate regression analysis (Table 4). Relapse (odds ratio: 8.49) was the most effective risk factor for mortality, followed by development of an IFI episode (odds ratio: 3.2 ) and AML (odds ratio: 2.33).

\section{Discussion}

We investigated a large sample of IFI data in children with acute leukemia, which provided a valuable assessment of IFI

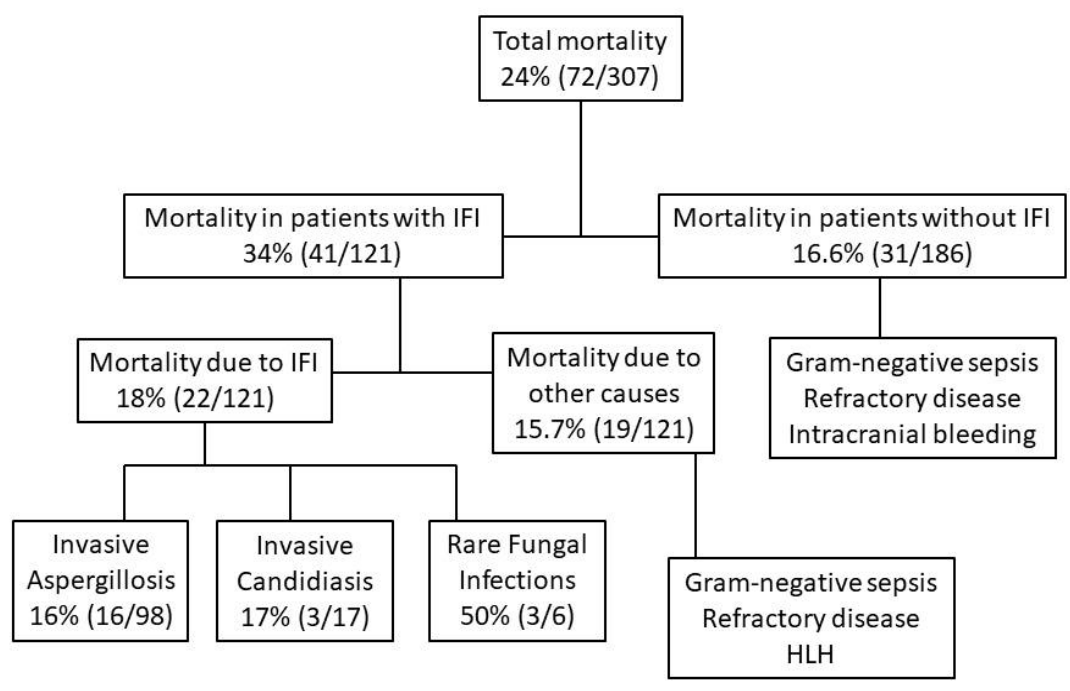

IFI: Invasive Fungal Infection, HLH: Secondary Hemophagocytic Lymphohistiocytosis

Figure 1. The rate and causes of mortality.

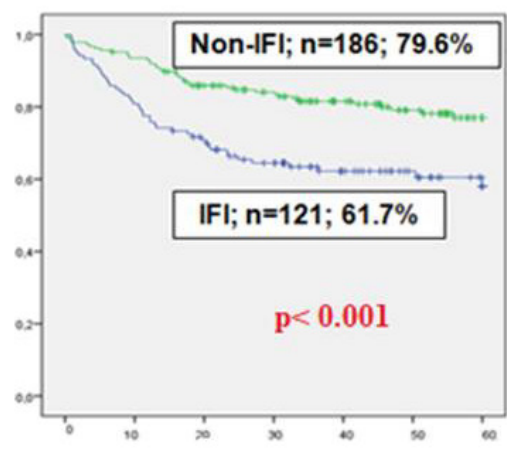

Figure 2a: Event-free survival

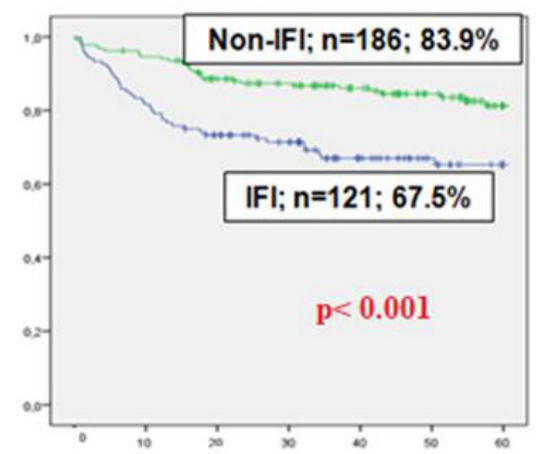

Figure $2 b$ : Overall survival

Figure 2. a). Event-free survival, b) Overall survival.

IFI: Invasive fungal infection

Table 4. Factors affecting mortality according to multivariate regression analysis.

\begin{tabular}{|l|l|l|l|l|} 
& B & $\mathbf{p}$ & Odds ratio & $\mathbf{9 5 \%}$ Cl \\
\hline Relapse & 2.14 & $<0.001$ & 8.49 & $3.98-18.1$ \\
\hline IFI episode & 1.18 & 0.001 & 3.2 & $1.58-6.75$ \\
\hline Leukemia type (AML) & 0.84 & 0.02 & 2.33 & $1.1-4.92$ \\
\hline AML: Acute myeloid leukemia, IFI: invasive fungal infection, Cl: confidence interval. & \\
\hline
\end{tabular}


epidemiology and outcomes in our country. In the current study, the incidence of IFI episodes was found to be $10.4 \%$. The incidence in cases of hematologic malignancies ranged between $1.7 \%$ and $35.4 \%$ in various studies $[4,9,10,11,12]$. However, it may increase further in autopsy findings [13]. The wide range among studies could be explained by differences in study populations, hospital conditions, usage of prophylactic antifungal agents, and the criteria used in defining IFI. The current study included only children with acute leukemia, and IFI attacks were defined according to EORTC/MSG criteria. The majority of attacks were in the group with possible IFls (73.2\%), since the use of invasive techniques such as bronchoalveolar lavage (BAL) was limited. The classification was mainly based on host factors, clinical criteria, imaging techniques, and serum GM levels. However, some of the cases within the possible group might be confirmed as Mucorales or other fungal diseases if histopathologic diagnosis methods are available, similarly to a case reported in the literature [14]. Among the present study group, proven and probable attacks were determined in 14.9\% and $11.9 \%$ of the cases, respectively. Proven and probable IFI incidences in recent studies with BFM groups were reported to be lower than $10 \%[15,16]$. Unlike our study, those two studies included not only hematologic malignancies but also hematopoietic stem cell transplantation recipients and antifungal prophylaxis was administered to the majority of them.

The mean age in the IFI group was significantly higher compared to children in the non-IFI group. The incidence of IFls is reported to increase with age $[4,7,17]$. This finding could be attributed to the fact that colonization is less frequent in the younger population due to less contact with fungal spores and the lower frequency of unfavorable genetic mutations $[1,18]$.

We found that children with ALL and AML had a similar frequency of experiencing at least one episode of IFI. This finding is contrary to the previous data in the literature suggesting that the frequency of IFI episodes in AML is higher than that in ALL $[4,19]$. The prevalence of IFI in ALL is reported to be between $4 \%$ and $35 \%$ depending on the era, chemotherapy protocol, risk categories, and antifungal prophylaxis $[6,7,12,17,20,21,22]$. In the current study, only $30 \%$ of children with ALL were receiving antifungal prophylaxis and the majority of them developed IFI during induction therapy or high-risk blocks, which are typically associated with severe neutropenia and high-dose steroids. Prolonged and severe neutropenia was defined as a determinant for IFI $[3,4]$. In our study, proven and probable IFI attacks also had a significantly longer mean duration of neutropenia than possible IFI attacks $(p=0.002)$. Similarly, reports from different countries showed that the majority of IFI attacks in both ALL and $A M L$ cases occurred during the induction phase and with more intensive chemotherapy protocols $[12,20,23,24,25]$. In developing countries, ALL patients receiving intensive chemotherapy phases may benefit from antifungal prophylaxis for decreasing IFI episodes in these patients.

The most common cause of IFI episodes in our study was IA $(81.9 \%)$, and the majority were cases of invasive pulmonary aspergillosis (IPA) (76.3\%). Aspergillus flavus was isolated from the sinonasal cavity in 3 out of 8 biopsy materials. After excluding possible IFI episodes, the proven and probable incidence of IA was 17\%. The incidences of IA and IPA have been increasing in patients with pediatric leukemia since 2000 with the use of new diagnostic methods $[4,26]$. Crassard et al. [5] showed that BAL results were suggestive of IPA in 92\% of children with pediatric leukemia. However, invasive procedures like BAL and biopsy are generally avoided in children due to thrombocytopenia and the risk of bleeding. Instead of biopsy, the combination of chest HRCT and serum GM level is more widely used for non-invasive diagnosis and it is also the preferred approach in Turkey. However, GM levels may not be elevated in localized IA, especially under antifungal prophylaxis or empiric antifungal treatment $[27,28]$.

The frequency of IC in total IFI episodes was found to be $13.4 \%$. However, it increased to $52.6 \%(n=10 / 19)$ among the proven IFI episodes. In our series, the incidence of hepatosplenic candidiasis (HSC) was determined as $7.8 \%$ and Candida spp. were isolated from blood cultures in 30\% of those cases. Celkan et al. [29], in a multicentric study from Turkey, recently reported that 8 out of $40(22.5 \%)$ children with HSC had Candida spp. and only one case was $C$. albicans. In the current study, the most commonly isolated pathogen was also non-albicans, namely $C$. parapsilosis (Table 2). It appears that $C$. albicans, which used to be the most commonly reported pathogen, has been replaced by $C$. parapsilosis and other non-albicans species $[6,12,19,30]$.

The current data showed a high rate of rare fungal infections, which were detected in 6 of $127 \mathrm{IFI}$ episodes (4.8\%). However, this incidence was increased to $31.5 \%(n=6 / 19)$ among proven attacks. Epidemiological data for children regarding rare fungal infections are limited $[14,31,32,33,34]$. Three out of 6 children had mucormycosis and the others had fusarium, dematiaceous, and alternaria involvements. The largest registry for invasive mucormycosis in children showed that its frequency was higher in cases of hematologic malignancies compared to other malignancies and a variety of other disorders $[31,32,33]$. A retrospective study from Italy also reported that underlying hematologic malignancies, particularly acute leukemia and lymphoma, are risk factors for developing mucormycosis [34]. Two patients with mucormycosis and one with fusarium died despite effective antifungal treatment combined with surgical resection. The mortality rates for both mucormycosis and fusarium are reported to be high $[31,33]$. Limited data related to dematiaceous and alternaria cases in children with leukemia are available in the literature $[35,36]$. In our study, these cases 
were successfully cured. The most important prognostic factor is early clinical suspicion, timely aggressive systemic antifungal treatment, and surgical procedures.

In the present study, the mortality rate for the whole cohort was $24 \%$ and the rate of deaths attributable to IFI was found to be $18 \%$. IFI-related mortality in cases of hematologic disorders ranged from $5 \%$ to $14 \%$ in Turkey $[10,12,37]$. It is also reported to be as high as $21 \%$ to $48 \%$ in children with leukemia $[7,21,38]$. The current study also separately analyzed the mortality rates for IA, IC, and rare fungal infections, which were found to be $16 \%, 17 \%$, and $50 \%$, respectively. The high mortality rate in the rare fungal infection subgroup still remains an important issue $[19,31]$. Although mortality rates due to IFls were reported high in the 1990s, they significantly decreased with the development of early diagnostic tools and new antifungal agents $[3,5,26,39]$.

Our data showed that OS and EFS were significantly lower in children with IFIs than those without IFIs. Multivariate regression analyses revealed that independent risk factors affecting mortality were recurrent disease, development of an IFI episode, and $A M L$, which increased the mortality rate 8.4, 3.2, and 2.3 times, respectively. Data on the impact of IFIs on survival rates in children with hematologic malignancies are rare. There are three major studies reported regarding this issue. Two of them did not find any differences in survival rates $[40,41]$. However, those studies included small numbers of children. Similar to our findings, Kobayashi et al. $[7,42]$ found significantly lower survival in patients with IFls compared to those without IFI in a patient population including hematologic malignancies, other malignant diseases, and aplastic anemia.

\section{Study Limitations}

The data were retrospectively collected. The classification was mainly based on host factors, clinical criteria, imaging techniques, and GM levels. BAL was not administered for any of the patients. Therefore, most of the attacks were in the "possible" group. However, it may have been seen that these cases were caused by other fungal pathogens if invasive techniques were available.

\section{Conclusion}

Proven and probable IFI episodes concurrently occurred in ALL, AML, and relapsed cases at rates of $19.5 \%, 31.8 \%$, and $55.5 \%$, respectively. Although the majority of attacks were related to $I A$, rare fungal infections were also isolated in almost 5\% of patients. Prolonged severe neutropenia was one of the major risk factors for IFls. Multivariate regression analysis showed that IFIs significantly increased mortality, and the survival rates were significantly lower in patients with IFIs. Our study clearly shows that IFIs are poor prognostic factors in children with hematologic malignancies.

\section{Ethics}

Ethics Committee Approval: The study was approved by the relevant ethics committee on October 4, 2016 (decision number 2016-17/12).

Informed Consent: Obtained.

\section{Authorship Contributions}

Concept: M.S.E., H.Ö., A.M.G., B.B., Ş.Y.; Data collection or processing: Ö.T., B.B., K.Ü.E., B.E., S.Ç., Ş.Y., M.E., M.K.H.; Analysis or interpretation: M.S.E., Ö.T., H.Ö., A.M.G., B.E., K.Ü.E., S.Ç., M.K.H.; Literature review: M.S.E., H.Ö., K.Ü.E., A.M.G.; Writing: M.S.E., H.Ö., A.M.G.

Conflicts of Interest: No conflicts of interest were declared by the authors.

Financial Disclosure: The authors declared that this study received no financial support.

Acknowledgments: The authors declared that they had no financial, consulting, or personal relationships with other people or organizations. This study was presented orally at the $44^{\text {th }}$ National Hematology Congress.

\section{References}

1. Pui CH, Yang JJ, Hunger SP, Pieters $R$, Schrappe M, Biondi A, Vora A, Baruchel A, Silverman LB, Schmiegelow K, Escherich G, Horibe K, Benoit YC, Izraeli S, Yeoh AE, Liang DC, Downing JR, Evans WE, Relling MV, Mullighan CG. Childhood acute lymphoblastic leukemia: progress through collaboration. J Clin Oncol 2015;33:2938-2948.

2. Hasle $H$, Kaspers GJ. Strategies for reducing the treatment-related physical burden of childhood acute myeloid leukaemia - a review. $\mathrm{Br} J$ Haematol 2017;176:168-178.

3. Groll AH, Castagnola $E$, Cesaro S, Dalle JH, Engelhard D, Hope W, Roilides E, Styczynski J, Warris A, Lehrnbecher T; Fourth European Conference on Infections in Leukaemia; Infectious Diseases Working Party of the European Group for Blood Marrow Transplantation (EBMT-IDWP); Infectious Diseases Group of the European Organisation for Research and Treatment of Cancer (EORTC-IDG); International Immunocompromised Host Society (ICHS); European Leukaemia Net (ELN). Fourth European Conference on Infections in Leukaemia (ECIL-4): guidelines for diagnosis, prevention, and treatment of invasive fungal diseases in paediatric patients with cancer or allogeneic haemopoietic stem-cell transplantation. Lancet Oncol 2014;15:e327-e340.

4. Ruijters VJ, Oosterom N, Wolfs TFW, van den Heuvel-Eibrink MM, van Grotel MJ. Frequency and determinants of invasive fungal infections in children with solid and hematologic malignancies in a nonallogeneic stem cell transplantation setting: a narrative review. Pediatr Hematol Oncol 2019;41:345-354.

5. Crassard N, Hadden $H$, Piens MA, Pondarré C, Hadden R, Galambrun C, Pracros JP, Souillet G, Basset T, Berthier JC, Philippe N, Bertrand Y. Invasive aspergillosis in a paediatric haematology department: a 15-year review. Mycoses 2008;51:109-116.

6. Mor M, Gilad G, Kornreich L, Fisher S, Yaniv I, Levy I. Invasive fungal infections in pediatric oncology. Pediatr Blood Cancer 2011;56:1092-1097.

7. Kobayashi R, Kaneda M, Sato T, Ichikawa M, Suzuki D, Ariga T. The clinical feature of invasive fungal infection in pediatric patients with hematologic 
and malignant diseases: a 10-year analysis at a single institution at Japan. J Pediatr Hematol Oncol 2008;30:886-890.

8. Lashkari HP, Fernandes N, Alva K, Rai S. Central nervous system fungal infection and acute lymphoblastic leukemia in children: what is the optimal duration of antifungal therapy? J Pediatr Hematol Oncol 2017;39:e312-e317.

9. De Pauw B, Walsh TJ, Donnelly JP, Stevens DA, Edwards JE, Calandra T, Pappas PG, Maertens J, Lortholary O, Kauffman CA, Denning DW, Patterson TF, Maschmeyer G, Bille J, Dismukes WE, Herbrecht R, Hope WW, Kibbler CC, Kullberg BJ, Marr KA, Muñoz P, Odds FC, Perfect JR, Restrepo A, Ruhnke M, Segal BH, Sobel JD, Sorrell TC, Viscoli C, Wingard JR, Zaoutis T, Bennett JE; European Organization for Research and Treatment of Cancer/ Invasive Fungal Infections Cooperative Group; National Institute of Allergy and Infectious Diseases Mycoses Study Group (EORTC/MSG) Consensus Group. Revised definitions of invasive fungal disease from the European Organization for Research and Treatment of Cancer/Invasive Fungal Infections Cooperative Group and the National Institute of Allergy and Infectious Diseases Mycoses Study Group EORTC/MSG) Consensus Group. Clin Infect Dis 2008;46:1813-1821.

10. Kaya Z, Gursel T, Kocak U, Aral YZ, Kalkanci A, Albayrak M. Invasive fungal infections in pediatric leukemia patients receiving fluconazole prophylaxis. Pediatr Blood Cancer 2009;52:470-475.

11. Tüfekçi Ö, Yılmaz Bengoa Ş, Demir Yenigürbüz F, Şimşek E, Hilkay Karapınar $\mathrm{T}$, İrken G, Ören H. Management of invasive fungal infections in pediatric acute leukemia and the appropriate time for restarting chemotherapy. Turk J Hematol 2015;32:329-337.

12. Sahbudak Bal Z, Yilmaz Karapinar D, Karadas N, Sen S, Onder Sivis Z, Akinci $A B$, Balkan C, Kavakli K, Vardar F, Aydinok Y. Proven and probable invasive fungal infections in children with acute lymphoblastic leukaemia: results from an university hospital, 2005-2013. Mycoses 2015;58:225-232.

13. Lehrnbecher T, Frank $C$, Engels $K$, Kriener $S$, Groll AH, Schwabe D. Trends in the postmortem epidemiology of invasive fungal infections at a university hospital. J Infect 2010;61:259-265.

14. Kebudi R, Kizılocak H, Hafiz G, Erturan Z. Successful outcome of mucormycosis in a child with acute lymphoblastic leukemia. Turk Pediatri Ars 2020;55:207-209.

15. Lehrnbecher T, Schöning S, Poyer F, Georg J, Becker A, Gordon K, Attarbaschi $A$, Groll AH. Incidence and outcome of invasive fungal diseases in children with hematological malignancies and/or allogeneic hematopoietic stem cell transplantation: results of a prospective multicenter study. Front Microbiol 2019;10:681.

16. Cesaro $S$, Tridello G, Castagnola E, Calore E, Carraro F, Mariotti I, Colombini A, Perruccio K, Decembrino N, Russo G, Maximova N, Baretta V, Caselli D. Retrospective study on the incidence and outcome of proven and probable invasive fungal infections in high-risk pediatric onco-hematological patients. Eur J Haematol 2017;99:240-248.

17. Rosen GP, Nielsen K, Glenn S, Abelson J, Deville J, Moore TB. Invasive fungal infections in pediatric oncology patients: 11-year experience at a single institution. J Pediatr Hematol Oncol 2005;27:135-140

18. Dini G, Castagnola E, Comoli P, van Tol MJ, Vossen JM. Infections after stem cell transplantation in children: state of the art and recommendations. Bone Marrow Transplant 2001;28(Suppl 1):S18-21.

19. Bartlett AW, Cann MP, Yeoh DK, Bernard A, Ryan AL, Blyth CC, Kotecha RS, McMullan BJ, Moore AS, Haeusler GM, Clark JE. Epidemiology of invasive fungal infections in immunocompromised children; an Australian national 10-year review. Pediatr Blood Cancer 2019;66:e27564.

20. Wang SS, Kotecha RS, Bernard A, Blyth CC, McMullan BJ, Cann MP, Yeoh DK, Bartlett AW, Ryan AL, Moore AS, Bryant PA, Clark J, Haeusler GM. Invasive fungal infections in children with acute lymphoblastic leukaemia: results from four Australian centres, 2003-2013. Pediatr Blood Cancer 2019;66:e27915.
21. Castagnola E, Cesaro $S$, Giacchino $M$, Livadiotti S, Tucci F, Zanazzo G, Caselli D, Caviglia I, Parodi S, Rondelli R, Cornelli PE, Mura R, Santoro N, Russo G, De Santis R, Buffardi S, Viscoli C, Haupt R, Rossi MR. Fungal infections in children with cancer: a prospective, multicenter surveillance study. Pediatr Infect Dis J 2006;25:634-639.

22. Hale KA, Shaw PJ, Dalla-Pozza L, MacIntyre CR, Isaacs D, Sorrell TC. Epidemiology of paediatric invasive fungal infections and a case-control study of risk factors in acute leukaemia or post stem cell transplant. Br J Haematol 2010;149:263-272.

23. Inaba H, Pei D, Wolf J, Howard SC, Hayden RT, Go M, Varechtchouk O, Hahn T, Buaboonnam J, Metzger ML, Rubnitz JE, Ribeiro RC, Sandlund JT, Jeha S, Cheng C, Evans WE, Relling MV, Pui CH. Infection-related complications during treatment for childhood acute lymphoblastic leukemia. Ann Oncol 2017;28:386-392.

24. Sun Y, Huang $H$, Chen J, Li J, Ma J, Li J, Liang Y, Wang J, Li Y, Yu K, Hu J, Jin J, Wang C, Wu D, Xiao Y, Huang X. Invasive fungal infection in patients receiving chemotherapy for hematological malignancy: a multicenter, prospective, observational study in China. Tumour Biol 2015;36:757-767.

25. Korula A, Abraham A, Abubacker FN, Viswabandya A, Lakshmi KM, Abraham OC, Rupali P, Varghese GM, Michael JS, Srivastava A, Mathews V, George B. Invasive fungal infection following chemotherapy for acute myeloid leukaemia-Experience from a developing country. Mycoses 2017;60:686691.

26. Lass-Flörl C. The changing face of epidemiology of invasive fungal disease in Europe. Mycoses 2009;52:197-205.

27. Kostamo K, Richardson M, Eerola E, Rantakokko-Jalava K, Meri T, Malmberg $\mathrm{H}$, Toskala E. Negative impact of Aspergillus galactomannan and DNA detection in the diagnosis of fungal rhinosinusitis. J Med Microbiol 2007;56(Pt 10):1322-1327.

28. Maertens J, Theunissen K, Lodewyck T, Lagrou K, Van Eldere J. Advances in the serological diagnosis of invasive Aspergillus infections in patients with haematological disorders. Mycoses 2007;50(Suppl 1):2-17.

29. Celkan T, Kizilocak H, Evim M, Meral Güneş A, Özbek NY, Yarali N, Ünal E, Patiroğlu T, Yilmaz Karapinar D, Sarper N, Zengin E, Karaman S, Koçak Ü, Kürekçi E, Özdemir C, Tuğcu D, Uysalol E, Dikme G, Adaletli i, Kuruoğlu $S$, Kebudi R. Hepatosplenic fungal infections in children with leukemiarisk factors and outcome: a multicentric study. J Pediatr Hematol Oncol 2019; $41: 256-260$.

30. Zaoutis T. Candidemia in children. Curr Med Res Opin 2010;26:1761-1768.

31. Pana ZD, Seidel D, Skiada A, Groll AH, Petrikkos G, Cornely OA, Roilides E; Collaborators of Zygomyco.net and/or FungiScope ${ }^{\text {TM }}$ Registries. Invasive mucormycosis in children: an epidemiologic study in European and nonEuropean countries based on two registries. BMC Infect Dis 2016;16:667.

32. Candoni A, Klimko N, Busca A, Di Blasi R, Shadrivova O, Cesaro S, Zannier $M E$, Verga $L$, Forghieri $F$, Calore $E$, Nadali G, Simonetti E, Muggeo P, Quinto AM, Castagnola C, Cellini M, Del Principe MI, Fracchiolla N, Melillo L, Piedimonte M, Zama D, Farina F, Giusti D, Mosna F, Capelli D, Delia M, Picardi M, Decembrino N, Perruccio K, Vallero S, Aversa F, Fanin R, Pagano L; SEIFEM Group (Epidemiological Surveillance of Infections in Haematological Diseases). Fungal infections of the central nervous system and paranasal sinuses in onco-haematologic patients. Epidemiological study reporting the diagnostic-therapeutic approach and outcome in 89 cases. Mycoses 2019;62:252-260.

33. Arnoni MV, Paula CR, Auler ME, Simões CCN, Nakano S, Szeszs MW, Melhem MSC, Pereira VBR, Garces HG, Bagagli E, Silva EG, de Macêdo MF, Ruiz LDS. Infections caused by Fusarium species in pediatric cancer patients and review of published literature. Mycopathologia 2018;183:941-949.

34. Muggeo $P$, Calore $E$, Decembrino $N$, Frenos $S$, De Leonardis $F$, Colombini $A$, Petruzziello F, Perruccio K, Berger M, Burnelli R, Zanazzo GA, Santoro N, Cesaro S. Invasive mucormycosis in children with cancer: a retrospective study from the Infection Working Group of Italian Pediatric Hematology Oncology Association. Mycoses 2019;62:165-170. 
35. Astolfo MF, Cañazares $P$, Majek E, Burgesser V, Caruso M, Basco J, Alvarado C, Carnovale S. Invasive acute sinusitis by Exserohilum rostratum in a patient with medullary relapse of acute lymphoblastic leukemia. Arch Argent Pediatr 2018;116:e594-e598.

36. Maloney AM, Ethier MC, Mitchell D, Zaoutis T, Sung L. Childhood Acute Myeloid Leukemia Infection Research Group. Alternaria sinusitis in children with acute myeloid leukemia: case reports from the Childhood Acute Myeloid Leukemia Infection Research Group. Leuk Lymphoma 2010:51:345-347.

37. Baytan B, Güneş AM, Çelebi S, Günay Ü. Invasive fungal diseases in children with hematologic disorders. Turk J Hematol 2009;26:190-196.

38. Blade J, Lopez-Guillermo A, Rozman C, Grañena A, Bruguera M, Bordas J, Cervantes F, Carreras E, Sierra J, Montserrat E. Chronic systemic candidiasis in acute leukemia. Ann Hematol 1992;64:240-244.
39. Groll AH, Kurz M, Schneider W, Witt V, Schmidt H, Schneider M, Schwabe D. Five-year-survey of invasive aspergillosis in a paediatric cancer centre. Epidemiology, management and long-term survival. Mycoses 1999;42:431442.

40. Ducassou S, Rivaud D, Auvrignon A, Vérité $C$, Bertrand $Y$, Gandemer V, Leverger G. Invasive fungal infections in pediatric acute myelogenous leukemia. Pediatr Infect Dis J 2015;34:1262-1264.

41. Kumar J, Singh $A$, Seth $R$, Xess I, Jana $M$, Kabra SK. Prevalence and predictors of invasive fungal infections in children with persistent febrile neutropenia treated for acute leukemia - a prospective study. Indian J Pediatr 2018;85:1090-1095

42. Kobayashi R, Hori D, Sano H, Suzuki D, Kishimoto K, Kobayashi K. Risk factors for invasive fungal infection in children and adolescents with hematologic and malignant diseases: a 10-year analysis in a single institute in Japan. Pediatr Infect Dis J 2018;37:1282-1285. 